\title{
Revising adrenal incidentalomas followup recommendations in CUA guideline
}

\section{Re: Guidelines for the management of the incidentally discovered adrenal mass (CUAJ, Aug 2011)}

\author{
Matthew McInnes, MD, FRCPC; Nicola Schieda, MD, FRCPC \\ Department of Radiology, School of Epidemiology and Public Health, University of Ottawa, Ottawa, ON, Canada
}

Cite as: Can Urol Assoc J 2021;15(4):E232. http://dx.doi.org/10.5489/cuaj.7267

W e are writing to suggest a small, but important point of clarification regarding the CUA guidelines for management of incidentally discovered adrenal mass. ${ }^{1}$ (see Editor's Note)

These are excellent and much-needed guidelines for what is a very common clinical scenario; however, we would like to discuss the followup recommendations in the guideline for adrenal incidentalomas (AI) with benign phenotype (computed tomograph [CT] density $<10 \mathrm{HU}$, benign CT washout characteristics, or loss of signal on chemical shift magnetic resonance imaging [MRI]).

The authors suggest that these lesions should be considered for followup in 12 months. While a single followup study might be argued to be of limited inconvenience to the patient, Als are common (estimated to be present in $4 \%$ of patients on imaging series ${ }^{2}$ ) and would be anticipated to result in a high number of unnecessary followup examinations and potential cost to the healthcare system. The authors' justification for this recommendation is that, "The risk of progression is not well-defined" and that "...it should be considered non-negligible." They quote the risk of developing malignancy as $0.1 \%$. The data provided in Table 1 of their article (one lesion out of 1913 was malignant) may not be accurate. Specifically, if one examines the paper by Tsvetov et al, which reports this case of malignancy, the malignancy was identified in a patient with known renal cell cancer: "FNA carried out in three patients (two oncological), revealed metastasis in one patient with known renal cell carcinoma." ${ }^{3}$ As such, we question whether this single case of malignancy should qualify as an AI by the definition provided in the guideline: "Adrenal incidentaloma is excluded in patients with known malignancy or high suspicion of malignant process."
A rate of $0 \%$ malignancy in $\mathrm{Al}$ is also supported by an evaluation of over 1000 Als with no malignancy identified. ${ }^{4}$ Given that the Al followup recommendation for benign phenotype is likely not justified by the evidence, and this recommendation, in our experience is driving a substantial number of unnecessary followup studies, we would like the CUA to consider aligning their recommendations with those of the American College of Radiology and European Society of Endocrinology, which state that masses with typical benign features of lipid-rich adenoma require no additional followup imaging.,

\section{References}

1. Kapoor A, Morris T, Rebello R. Guidelines for the management of the incidentally discovered adrenal mass. Can Urol Assoc J 2011;5:241-7. https://doi.org/10.5489/cuaj.11135

2. Bovio $S$, Cataldi A, Reimondo $G$, et al. Prevalence of adrenal incidentaloma in a contemporary computerized tomography series. J Endocrinol Invest 2006;29:298-302. https://doi.org/10.1007/BF03344099

3. Tsvetov G, Shimon I, Benbassat C. Adrenal incidentaloma: clinical characteristics and comparison between patients with and without extra-adrenal malignancy. J Endocrinol Invest 2007;30:647-52. https://doi.org/10.1007/BF03347444

4. Song JH, Chaudhry FS, Mayo-Smith WW. The incidental adrenal mass on CT: Prevalence of adrenal disease in 1049 consecutive adrenal masses in patients with no known malignancy. AJR Am J Roentgenol 2008;190:1163-8. https://doi.org/10.2214/AJR.07.2799

5. Fassnacht M, Arlt W, Bancos I, et al. Management of adrenal incidentalomas: European Society of Endocrinology Clinical Practice Guideline in collaboration with the European Network for the Study of Adrenal Tumors. Eur J Endocrinol 2016;175:G1-34. https://doi.org/10.1530/EJE-16-0467

6. Mayo-Smith WW, Song JH, Boland GL, et al. Management of incidental adrenal masses: A white paper of the ACR Incidental Findings Committee. J Am Coll Radiol 2017;14:1038-44. https://doi.org/10.1016/i. jacr.2017.05.001

Correspondence: Dr. Matthew Mclnnes, Department of Radiology, School of Epidemiology and Public Health, University of Ottawa, Ottawa, ON, Canada; mminnes@toh.ca

EDITOR'S NOTE: An update of the CUA guideline for the management of incidentally discovered adrenal mass is currently underway. The update is expected to be released by the end of 2021. 